\title{
Relationship between Levels of Intercultural Sensitivity and Emotional Intelligence amongst Preservice Social Studies Teachers
}

\author{
Arcan AYDEMIR ${ }^{1}$ \\ Artvin Çoruh University, Artvin, TURKEY
}

\author{
Özlem ULU KALIN ${ }^{2}$ \\ Artvin Çoruh University, Artvin, TURKEY
}

${ }^{1}$ Corresponding author: Ph.D.. Artvin Çoruh University, Faculty of Education, Department of Turkish and Social Sciences Education, Artvin, TURKEY. arcan.aydemir [at] hotmail.com. ORCID: 0000-0001-8110-954X

${ }^{2}$ Assoc. Prof.. Artvin Çoruh University, Faculty of Education, Department of Turkish and Social Sciences Education, Artvin, TURKEY. ozlemulu [at] artvin.edu.tr ORCID: 0000-0001-9317-5261

\begin{abstract}
This study focused on the levels of intercultural sensitivity and emotional intelligence demonstrated by preservice Social Studies teachers' and sought to explore the relationship between the two variables. The study used a correlational survey research design. The sample consisted of 274 pre-service Social Studies teachers who were in different years of study. The data were collected using the "Intercultural Sensitivity Scale", "Emotional Intelligence Scale", and a "Personal Information Form". The data were analyzed using the independent samples T-test and one-way Analysis Of Variance (ANOVA). The correlation co-efficient was also computed to identify the relationship between intercultural sensitivity and emotional intelligence. The analysis results showed that the intercultural sensitivity of pre service Social Studies teachers' differed significantly according to gender and them having friends from different countries or cultures; while their emotional intelligence differed significantly according to having friends from different countries or cultures. A significant moderate positive correlation was found between intercultural sensitivity and emotional intelligence. Further research may contribute to the literature by studying emotional intelligence and intercultural sensitivity in sample groups from different areas or with different characteristics.
\end{abstract}

\section{Keywords}

Sensitivity; Intercultural Sensitivity; Emotional Intelligence

To cite this article: Aydemir, A.; Ulu Kalın, Ö. (2021). Relationship between levels of intercultural sensitivity and emotional intelligence amongst preservice social studies teachers. Review of International Geographical Education (RIGEO), 11(2), 410-428. doi: 10.33403rigeo.759860 
Since the Renaissance, there has been a belief that the mind symbolizes all that is good, right, and strong, whereas emotions reflect people's weaknesses. With the Industrial Revolution triggered by the discovery of steam, the absolute superiority of the mind over emotions has become a reality for society, which does not even need to be questioned. The myth of rationality has evolved, and the view has become widespread that rationality is the solution to all problems, whereas emotions impede rationality (Robbins, 2000).

Along with studies in Psychology in the early 20th Century and scientific advancements, the social reactions of European people since the 1960s, through the free expression of their feelings have revealed that emotions are not separate from intellectual activities and are critically important for the sustainability of life (Çakar \& Arbak, 2004). In this context, emotional intelligence is defined as three categories of adaptive abilities: evaluating one's own and others' emotions; regulating emotions; and using emotions in problem-solving (Yllmaz-Karabulutlu et al., 2011). Emotional intelligence represents people's impulses, needs and real values that drive all apparent behavior (Güllüce \& İşcan, 2010). Drawing on the concept of emotional intelligence to encourage new expansions in different areas, studies focus on measuring emotional intelligence and exploring sub-dimensions, such as how to improve emotional intelligence. The development of emotional intelligence is intertwined with developmental processes such as cognitive and biological maturation (Yeșilyaprak, 2001). The three main factors to consider in the development of emotional intelligence include family environment, age, and gender (Tuğrul, 1999). People with well-developed emotional intelligence can also develop the ability to control their emotions and lead a high-quality life by eliminating negative emotions such as anxiety and stress from their lives. They can also develop self-belief (Dutoğlu \& Tuncel, 2008).

Culture is also affected by emotions and has diverse impacts at different stages of life. Culture is a concept that can be defined in various ways as its meaning may vary depending on the area of study (Karaca \& Gümüş, 2018). Culture is a social phenomenon that arises as a result of social life (Aydın, 2014). Therefore, diversity in social characteristics causes cultural differences by creating distinctive cultures. Intercultural sensitivity is needed to prevent cultural differences from causing intercultural problems. The concept of intercultural sensitivity is generally considered as a multidimensional construct and used in different theoretical aspects (Tamam \& Krauss, 2017). Intercultural sensitivity involves being sensitive to cultural differences and perspectives of people from different cultures (Bhawuk \& Brislin, 1992). Intercultural sensitivity focuses on people's subjective experiences and their interpretation of and responses to cultural differences (Fuller, 2007). Bennett (1998) drew attention to two stages in his developmental model of intercultural sensitivity. He divided intercultural sensitivity into two stages: ethnocentric, and ethno relative. The ethnocentric stage generally refers to the stage when people unconsciously judge others by their own merits, whereas the ethno relative stage covers the time when people experience other cultural contexts. The ethnocentric stage consists of the steps of denial, defense, and minimization, whereas the ethno relative stage includes the steps of acceptance, adaptation, and integration (Bennett, 1998, as cited in Üstün, 2011). 
Individuals raised in contemporary societies are expected to develop positive attitudes towards different cultures and have intercultural sensitivity (Cirlk, 2008). Educational institutions and educators play a key role in ensuring that individuals have the expected characteristics. Among the factors that directly affect the efficiency of education, the qualifications of teachers do influence expected behaviors of students. Thus, teachers first must have intercultural sensitivity to help students become sensitive to different cultures. Teachers' ability to show intercultural sensitivity depends on the creation of appropriate educational situations (Yılmaz \& Göçen, 2013). Therefore, education faculties should know the intercultural sensitivity levels of pre-service teachers who are studying different disciplines.

Sensitivity is closely related to emotions. Experiences with individuals or situations with different cultural characteristics may shape feelings about them and cultural differences (Rengi, 2014). Intercultural sensitivity is evaluated in the affective dimension as the process of emotional development (Chen, 1997; Chen \& Starosta, 1996). Emotional intelligence, on the other hand, involves recognising and evaluating one own's and others' feelings (Yeşilyaprak, 2001). Individuals with intercultural sensitivity should have a desire to motivate themselves in order to understand, accept and appreciate differences between cultures (Chen, 1997). Goleman (1998) also used the term self-motivation when describing emotional intelligence (as cited in Acar, 2002). Accordingly, emotional intelligence and intercultural sensitivity are interrelated. This study was conducted to find out whether these two interrelated phenomena support the data obtained as a result of the study.

The reason for sampling pre-service Social Studies teachers was that emotional intelligence and intercultural sensitivity are directly linked to the purpose of Social Studies education. The purpose of Social Studies education is "to prepare citizens of the Republic of Turkey who comprehend Turkish history and culture, are equipped with fundamental democratic values, respectful to human rights and sensitive to their environment, interpret information based on their experiences, create, use and organise information in a social and cultural context, have advanced social engagement skills, adopt the method that social scientists use to produce scientific information, are active and productive in social life, and know their rights and responsibilities" (Koçoğlu, 2014). In the Social Studies curricula (MoNE [Ministry of National Education], 2005; MoNE, 2018), the learning areas "Culture and Heritage" and "Global Connections" focus on the following themes: culture, cultural sensitivity, the introduction of foreign cultures, tolerance, and respect. Additionally, especially in Social Studies Teacher Education Programmes (CoHE [Council of Higher Education], 2018), various elective courses (for example, language and culture, and human relations and communication) and compulsory courses (for example, media literacy education, and civics) discuss topics such as culture and multiculturalism. Thus, pre-service Social Studies teachers' levels of intercultural sensitivity and emotional intelligence are expected to be interrelated.

A considerable volume of research has been conducted on both intercultural sensitivity (Abaslı \& Polat, 2019; Mercan, 2016; Onur-Sezer \& Bahçeli-Kahraman, 2017; Ögüt, 2017; Üstün, 2011; Vilà-Baños, 2006; Westrick \& Yuen, 2007; Yılmaz \& 
Göçen, 2013; Yuen \& Grossman, 2009) and emotional intelligence (Cook, 2006; Delice \& Günbeyi, 2013; Erdoğdu, 2008; Girgin, 2009; Kayıhan, 2017; Muștu, 2019; Öztürk, 2006; Sudak \& Zehir, 2013; Yılmaz \& Zembat, 2019). However, the literature lacks research that investigates the relationship between intercultural sensitivity and emotional intelligence, in particular, amongst pre-service Social Studies teachers.

\section{Research Purpose}

The main purpose of the research was to explore the relationship between the levels of intercultural sensitivity and emotional intelligence amongst pre-service Social Studies teachers'. To this end, answers were sought to the following questions:

- Does the intercultural sensitivity of pre-service Social Studies teachers' differ significantly according to gender, year of study, type of high school attended, residence of longest duration, having friends from different countries or cultures, and the experience of having been abroad?

- Does the emotional intelligence of pre-service Social Studies teachers' differ significantly according to gender, year of study, type of high school attended, residence of longest duration, having friends from different countries or cultures, and the experience of having been abroad?

- Is there a significant relationship between the levels of intercultural sensitivity and emotional intelligence amongst pre-service Social Studies teachers'?

\section{Methodology}

\section{Research Design}

The study used a correlational survey research design. Correlational research explores the relationships between the previously defined variables (Sönmez \& Alacapınar, 2019). Correlational research explains the relationships between variables and allows making some predictions based on results (Tekbiyık, 2019). Accordingly, the relationship between the emotional intelligence and intercultural sensitivity of pre-service Social Studies teachers in different years of study were investigated using a correlation survey research design in line with the main purpose of the study.

\section{Population and Sample}

The population was composed of students studying to be Social Studies teachers from three different universities in the Black Sea, Marmara, and Eastern Anatolia regions. The sample consisted of pre-service Social Studies teachers who were selected through simple random sampling and volunteered to participate in the study. The reason for adopting the simple random sampling method was that each unit has an equal chance of being selected for the sample (Özdemir et al., 2019). Table 1 contains data about the sample. 
Table 1

Data about the Sample

\begin{tabular}{|c|c|c|c|}
\hline Variable Type & & $\begin{array}{l}\text { Frequency } \\
(f)\end{array}$ & $\begin{array}{l}\text { Per cent } \\
(\%)\end{array}$ \\
\hline \multirow{3}{*}{ Gender } & Female & 197 & 71.9 \\
\hline & Male & 77 & 28.1 \\
\hline & Total & 274 & 100 \\
\hline \multirow{5}{*}{ Year of Study } & $1^{\text {st }}$ year & 58 & 21.2 \\
\hline & $2^{\text {nd }}$ year & 71 & 25.9 \\
\hline & $3^{\text {rd }}$ year & 39 & 14.2 \\
\hline & $4^{\text {th }}$ year & 106 & 38.7 \\
\hline & Total & 274 & 100 \\
\hline \multirow{5}{*}{$\begin{array}{l}\text { Type of high school } \\
\text { attended }\end{array}$} & $\begin{array}{l}\text { Academic/basic/regular high } \\
\text { school }\end{array}$ & 61 & 22.3 \\
\hline & Anatolian high school & 146 & 53.3 \\
\hline & $\begin{array}{l}\text { Imam Hatip (religious) high } \\
\text { school }\end{array}$ & 35 & 12.8 \\
\hline & Vocational high school & 32 & 11.7 \\
\hline & Total & 274 & 100 \\
\hline \multirow{4}{*}{$\begin{array}{l}\text { Residence of longest } \\
\text { duration }\end{array}$} & Province & 108 & 39.4 \\
\hline & District & 88 & 31.1 \\
\hline & Village & 78 & 28.5 \\
\hline & Total & 274 & 100 \\
\hline \multirow{3}{*}{$\begin{array}{l}\text { Having friends from } \\
\text { different countries or } \\
\text { cultures }\end{array}$} & Yes & 183 & 66.8 \\
\hline & No & 91 & 33.2 \\
\hline & Total & 274 & 100 \\
\hline \multirow[t]{3}{*}{ Having been abroad } & Yes & 70 & 25.5 \\
\hline & No & 204 & 74.5 \\
\hline & Total & 274 & 100 \\
\hline
\end{tabular}

As seen in Table 1, among 274 pre-service Social Studies teachers, 197 were female and 77 were male. Most of the participants were in their fourth year of study ( $\mathrm{f}=106, \% 38.7$ ), graduated from an Anatolian high school ( $\mathrm{f}=146, \% 53.3$ ), lived longest in a province ( $\mathrm{f}=108, \% 39.4$ ), had a friend or friends from different countries or cultures ( $f=183, \% 66.8)$, and had never been abroad ( $f=204, \% 70)$.

\section{Data Collection Instruments}

The data were collected using the "Intercultural Sensitivity Scale" (ISS) developed by Chen and Starosta (2000) and adapted to Turkish by Üstün (2011). Data were also collected using the "Emotional Intelligence Scale" (EIS) developed by Lee and Kwak (2012) and adapted by Kayıhan and Arslan (2016). There was also a personal information form designed by the researchers in relation to the investigated variables.

Emotional intelligence scale (EIS). The EIS developed by Lee and Kwak (2012) and adapted into Turkish by Kayıhan and Arslan (2016). The EIS was used to determine the levels of emotional intelligence amongst pre-service Social Studies teachers. The Turkish version of Cronbach's alpha co-efficient was computed as .83. For the sub-scales, the Cronbach's alpha co-efficient was found to be .72 for the emotional recognition/understanding sub-scale; .71 for the emotional facilitation 
subs-scale; and .76 for the emotional regulation sub-scale. A 5-point Likert-type scale consisting of 20 items under 3 sub-scales was obtained (Kayıhan \& Arslan, 2016). In the present study, the Cronbach's alpha was found to be .87 for the entire scale; .73 for the emotional recognition/understanding sub-scale; .66 for the emotional facilitation sub-scale, and .86 for the emotional regulation sub-scale.

Intercultural sensitivity scale (ISS). The ISS developed by Chen and Starosta (2000) and adapted to Turkish by Üstün (2011) was used to determine the levels of intercultural sensitivity of pre-service Social Studies teachers. Üstün (2011) computed the Cronbach's alpha co-efficient of the original form as .88 and that of the adapted Turkish version as .90. These values show that the scale has a high internal consistency. The original scale has five factors, however, the Turkish version has a single factor. As a result of the validity and reliability tests, a 5-point Likert-type scale consisting of 23 items was obtained (Üstün, 2011). The Cronbach's alpha co-efficient was found to be .83 in the present study.

Personal information form. The personal information form consisted of various questions about gender, year of study, type of high school attended, residence of longest duration, having friends from different countries or cultures, and the experience of having been abroad.

\section{Data Analysis}

The data were analyzed using SPSS statistical software version 22. The Kolmogorov-Smirnov test results and the skewness and kurtosis values were analyzed to determine whether the data gathered from both scales are normally distributed in relation to the investigated variables. The analysis results showed the data from both scales are normally distributed in relation to the investigated variables (i.e. gender, year of study, type of high school attended, and residence of longest duration, having friends from different countries or cultures, and the experience of having been abroad). Thus, the data were analyzed using the independent samples T-test and one-way ANOVA. The mean scores on both scales were used for the data analysis. The Pearson product-moment correlation coefficient (PPMCC) was computed to determine the relationship between the levels of intercultural sensitivity and emotional intelligence. The level of significance was taken as $\mathrm{p}<.01$ for the calculation of correlation co-efficient and $\mathrm{p}<.05$ for other analyses. The co-efficient value lying between .70 and 1.00 was considered high, the co-efficient value between .30 and .70 was considered moderate, and the co-efficient value between .00 and .30 was considered low (Büyüköztürk, 2011).

\section{Findings}

The data were analyzed using different tests according to the number of categories in the variables. Emotional intelligence levels were obtained from the mean total score on the entire scale and the scores on three subscales (emotional recognition/understanding, emotional facilitation, and emotional regulation). Table 2 shows the results of the descriptive statistics for the scores of pre-service Social Studies teachers on the ISS and EIS. 
Table 2

Results Of The Descriptive Statistics For Preservice Social Studies Teachers' Scores On The ISS And EIS

\begin{tabular}{lccccc}
\hline & $\mathrm{N}$ & Minimum & Maximum & $\mathrm{X}$ & $\mathrm{SD}$ \\
\hline Intercultural Sensitivity & 274 & 2.61 & 4.83 & 4.05 & .44 \\
\hline Emotional Intelligence & 274 & 2.05 & 5.00 & 3.86 & .56 \\
\hline $\begin{array}{l}\text { Emotional Intelligence Subscale 1: } \\
\begin{array}{l}\text { Emotional Recognition/ } \\
\text { Understanding }\end{array}\end{array}$ & 274 & 2.00 & 5.00 & 4.13 & .58 \\
\hline $\begin{array}{l}\text { Emotional Intelligence Subscale 2: } \\
\text { Emotional Facilitation }\end{array}$ & 274 & 1.67 & 5.00 & 3.74 & .69 \\
\hline $\begin{array}{l}\text { Emotional Intelligence Subscale 3: } \\
\text { Emotional Regulation }\end{array}$ & 274 & 1.00 & 5.00 & 3.74 & .75 \\
\hline
\end{tabular}

As shown in Table 2, participants' mean score on the ISS $(\bar{X}=4.05)$ was higher than their scores on the EIS ( $\bar{X}=3.86)$. Apropos of the mean scores on the sub-scales of the EIS, the highest mean score was recorded on the emotional recognition/understanding $(\bar{X}=4.13)$.

Table 3 presents the T-test results for the levels of intercultural sensitivity and emotional intelligence in relation to the gender of pre-service Social Studies teachers participants.

Table 3

T-Test Results for the Levels of Intercultural Sensitivity and Emotional Intelligence according to the Gender of Pre-service Social Studies Teachers participants

\begin{tabular}{llcccccc}
\hline & Gender & $\mathrm{N}$ & $\mathrm{X}$ & $\mathrm{SD}$ & $\mathrm{df}$ & $\mathrm{t}$ & $\mathrm{p}$ \\
\hline Intercultural Sensitivity & Female & 197 & 4.09 & .43 & 272 & 2.377 & $.018^{*}$ \\
& Male & 77 & 3.94 & .47 & & & \\
\hline Emotional Intelligence & Female & 197 & 3.88 & .56 & 272 & 1.020 & .309 \\
& Male & 77 & 3.80 & .55 & & & \\
\hline Emotional Intelligence & Female & 197 & 4.14 & .57 & 272 & .509 & .611 \\
Subscale 1: Emotional & Male & 77 & 4.10 & .59 & & & \\
Recognition/ Understanding & & & & & & & \\
\hline Emotional Intelligence & Female & 197 & 3.78 & .68 & 272 & 1.439 & .151 \\
Subscale 2: Emotional & Male & 77 & 3.64 & .71 & & & \\
Facilitation & & & & & & & \\
\hline Emotional Intelligence & Female & 197 & 3.76 & .75 & 272 & .620 & .536 \\
Subscale 3: Emotional & Male & 77 & 3.70 & .75 & & & \\
Regulation & & & & & & & \\
\hline
\end{tabular}

$* \mathrm{p}<.05$

It is apparent from Table 3 that pre-service Social Studies teachers' levels of intercultural sensitivity levels differed significantly by gender $(\mathrm{t}(272)=2.377, \mathrm{p}<$ $.05)$. Given the arithmetic mean of the scores obtained by female participants $(\overline{\mathrm{x}}=$ 4.09) and male participants ( $\bar{X}=3.94)$ on the ISS, the difference was in favor of female participants. This result suggests that female participants have a higher level of intercultural sensitivity compared to male participants. On the other hand, there was no significant difference between male and female participants in terms of their scores on the EIS $(\mathrm{t}(272)=1.020, \mathrm{p}>.05)$ and its sub-scales of emotional 
Aydemir, A.; Ulu Kalın, Ö. (2021). Relationship between levels of intercultural sensitivity and...

recognition/understanding $(\mathrm{t}(272)=.509, \mathrm{p}>.05)$, emotional facilitation $\mathrm{t}(272)=$ $1.439, \mathrm{p}>.05)$, and emotional regulation $(\mathrm{t}(272)=.620, \mathrm{p}>.05)$.

Table 4 demonstrates the ANOVA results for rs' levels of intercultural sensitivity and emotional intelligence in relation to the year of study of the pre-service Social Studies teacher participants.

Table 4

ANOVA Results for the Levels of Intercultural Sensitivity and Emotional Intelligence according to the year of study of the Preservice Social Studies Teacher participants

\begin{tabular}{lccccccc}
\hline & $\begin{array}{c}\text { Year of } \\
\text { Study }\end{array}$ & $\mathrm{N}$ & $\mathrm{X}$ & $\mathrm{SD}$ & $\mathrm{df}$ & $\mathrm{F}$ & $\mathrm{p}$ \\
\hline Intercultural & 1 & 58 & 4.05 & .46 & & & \\
Sensitivity & 2 & 71 & 3.97 & .47 & $3-$ & 1.400 & .243 \\
& 3 & 39 & 4.00 & .38 & 270 & & \\
& 4 & 106 & 4.11 & .43 & & & \\
Emotional & 1 & 58 & 3.88 & .64 & & & \\
Intelligence & 2 & 71 & 3.85 & .60 & $3-$ & .055 & .983 \\
& 3 & 39 & 3.84 & .50 & 270 & & \\
\hline Emotional & 4 & 106 & 3.85 & .51 & & & \\
Intelligence Subscale & 1 & 58 & 4.13 & .62 & & & \\
1: Emotional & 2 & 71 & 4.14 & .64 & $3-$ & .158 & .925 \\
Recognition/ & 3 & 39 & 4.17 & .55 & 270 & & \\
Understanding & 4 & 106 & 4.10 & .53 & & & \\
Emotional & & & & & & & \\
Intelligence Subscale & 2 & 71 & 3.73 & .66 & $3-$ & .381 & .767 \\
2: Emotional & 3 & 39 & 3.64 & .65 & 270 & & \\
Facilitation & 4 & 106 & 3.75 & .68 & & & \\
\hline Emotional & 1 & 58 & 3.76 & .85 & & & \\
Intelligence Subscale & 2 & 71 & 3.73 & .80 & $3-$ & .022 & .996 \\
3: Emotional & 3 & 39 & 3.74 & .74 & 270 & & \\
Regulation & 4 & 106 & 3.75 & .76 & & & \\
\hline
\end{tabular}

Looking at Table 4, it is apparent that neither intercultural sensitivity $(\mathrm{F}(3-270)=$ $1.400, \mathrm{p}>.05)$ nor emotional intelligence levels $(\mathrm{F}(3-270)=.055, \mathrm{p}>.05)$ of preservice Social Studies teachers significantly differed according to their year of study. There was also no significant difference in terms of the year of study between participants' scores on the emotional intelligence subscales of emotional recognition/understanding $(\mathrm{F}(3-270)=.158, \mathrm{p}>.05)$, emotional facilitation $(\mathrm{F}(3-$ $270)=.381, \mathrm{p}>.05)$, and emotional regulation $(\mathrm{F}(3-270)=.022, \mathrm{p}>.05)$. This result indicates that the year of study did not lead to a significant difference in the levels of intercultural sensitivity and emotional intelligence amongst pre-service Social Studies teacher.

Table 5 displays the results of ANOVA for the levels of intercultural sensitivity and emotional intelligence in relation to the type of high school attended by the preservice Social Studies teacher participants. 
Table 5

ANOVA Results for the Levels of Intercultural Sensitivity and Emotional Intelligence according to the Type of High School Attended by the Preservice Social Studies Teacher participants

\begin{tabular}{|c|c|c|c|c|c|c|c|}
\hline & Type of High School & $\mathrm{N}$ & $\mathrm{X}$ & SD & df & $\mathrm{F}$ & $\mathrm{p}$ \\
\hline \multirow{4}{*}{$\begin{array}{l}\text { Intercultural } \\
\text { Sensitivity }\end{array}$} & $\begin{array}{l}\text { Academic/basic/regular } \\
\text { high school }\end{array}$ & 61 & 4.02 & .51 & \multirow{4}{*}{$\begin{array}{c}3- \\
270\end{array}$} & \multirow{4}{*}{1.976} & \multirow{4}{*}{.118} \\
\hline & Anatolian high school & 146 & 4.09 & .41 & & & \\
\hline & $\begin{array}{l}\text { Imam Hatip (religious) } \\
\text { high school }\end{array}$ & 35 & 3.89 & .41 & & & \\
\hline & Vocational high school & 32 & 4.05 & .48 & & & \\
\hline \multirow{4}{*}{$\begin{array}{l}\text { Emotional } \\
\text { Intelligence }\end{array}$} & $\begin{array}{l}\text { Academic/basic/ } \\
\text { regular high school }\end{array}$ & 61 & 3.87 & .57 & \multirow{4}{*}{$\begin{array}{c}3- \\
270\end{array}$} & \multirow{4}{*}{.516} & \multirow{4}{*}{.671} \\
\hline & Anatolian high school & 146 & 3.86 & .54 & & & \\
\hline & $\begin{array}{l}\text { Imam Hatip (religious) } \\
\text { high school }\end{array}$ & 35 & 3.76 & .62 & & & \\
\hline & Vocational high school & 32 & 3.92 & .55 & & & \\
\hline \multirow{5}{*}{$\begin{array}{l}\text { Emotional } \\
\text { Intelligence } \\
\text { Subscale 1: } \\
\text { Emotional } \\
\text { Recognition/ } \\
\text { Understanding }\end{array}$} & $\begin{array}{l}\text { Academic/basic/regular } \\
\text { high school }\end{array}$ & 61 & 4.05 & .54 & \multirow{5}{*}{$\begin{array}{c}3- \\
270\end{array}$} & \multirow{5}{*}{1.271} & \multirow{5}{*}{.285} \\
\hline & Anatolian high school & 146 & 4.17 & .56 & & & \\
\hline & Imam Hatip (religious) & 35 & 4.01 & .64 & & & \\
\hline & high school & & & & & & \\
\hline & Vocational high school & 32 & 4.20 & .64 & & & \\
\hline \multirow{4}{*}{$\begin{array}{l}\text { Emotional } \\
\text { Intelligence } \\
\text { Subscale } \\
\text { Emotional } \\
\text { Facilitation }\end{array}$} & $\begin{array}{l}\text { Academic/basic/regular } \\
\text { high school }\end{array}$ & 61 & 3.79 & .69 & \multirow{4}{*}{$\begin{array}{c}3- \\
270\end{array}$} & \multirow{4}{*}{1.242} & \multirow{4}{*}{.295} \\
\hline & Anatolian high school & 146 & 3.74 & .65 & & & \\
\hline & $\begin{array}{l}\text { Imam Hatip (religious) } \\
\text { high school }\end{array}$ & 35 & 3.68 & .81 & & & \\
\hline & Vocational high school & 32 & 3.80 & .67 & & & \\
\hline \multirow{4}{*}{$\begin{array}{l}\text { Emotional } \\
\text { Intelligence } \\
\text { Subscale } \\
\text { Emotional } \\
\text { Regulation }\end{array}$} & $\begin{array}{l}\text { Academic/basic/regular } \\
\text { high school }\end{array}$ & 61 & 3.79 & .77 & \multirow{4}{*}{$\begin{array}{c}3- \\
270\end{array}$} & \multirow{4}{*}{.148} & \multirow{4}{*}{.931} \\
\hline & Anatolian high school & 146 & 3.72 & .77 & & & \\
\hline & $\begin{array}{l}\text { Imam Hatip (religious) } \\
\text { high school }\end{array}$ & 35 & 3.73 & .75 & & & \\
\hline & Vocational high school & 32 & 3.78 & .65 & & & \\
\hline
\end{tabular}

As seen in Table 5, pre-service Social Studies teachers' scores on the ISS (F(3$270)=1.976, \mathrm{p}>.05)$, the entire EIS $(\mathrm{F}(3-270)=.516, \mathrm{p}>.05)$, and its sub-scales (emotional recognition /understanding $[\mathrm{F}(3-270)=1.271, \mathrm{p}>.05]$, emotional facilitation $[F(3-270)=1.242, p>.05]$, and emotional regulation $[F(3-270)=.148, p$ $>$.05]) did not differ statistically significantly according to the type of high school attended.

Table 6 displays the ANOVA results for levels of intercultural sensitivity and emotional intelligence in relation to the residence of longest duration from preservice Social Studies teachers' participants. 
Aydemir, A.; Ulu Kalın, Ö. (2021). Relationship between levels of intercultural sensitivity and...

Table 6

ANOVA Results for Levels of Intercultural Sensitivity and Emotional Intelligence according to the Residence of Longest Duration from Pre-service Social Studies Teachers participants

\begin{tabular}{|c|c|c|c|c|c|c|c|c|}
\hline & $\begin{array}{l}\text { Place of } \\
\text { Residence }\end{array}$ & $\mathrm{N}$ & $X$ & SD & $\mathrm{df}$ & $\mathrm{F}$ & $\mathrm{p}$ & Difference \\
\hline Intercultural & $\begin{array}{l}\text { Province } \\
\text { (1) }\end{array}$ & 108 & 4.13 & .44 & $2-$ & & & \\
\hline \multirow[t]{2}{*}{ Sensitivity } & District (2) & 88 & 4.00 & .46 & 271 & 3.667 & .027 & $1-3$ \\
\hline & Village (3) & 78 & 3.97 & .41 & & & & \\
\hline Emotional & $\begin{array}{l}\text { Province } \\
\text { (1) }\end{array}$ & 108 & 3.95 & .54 & $2-$ & & & \\
\hline \multirow[t]{2}{*}{ Intelligence } & District (2) & 88 & 3.91 & .58 & 271 & 2.429 & .090 & \\
\hline & Village (3) & 78 & 3.79 & .54 & & & & \\
\hline $\begin{array}{l}\text { Emotional } \\
\text { Intelligence }\end{array}$ & $\begin{array}{l}\text { Province } \\
\text { (1) }\end{array}$ & 108 & 4.19 & .56 & $2-$ & & & \\
\hline Subscale 1: & District (2) & 88 & 4.14 & .62 & 271 & 1.860 & .158 & \\
\hline $\begin{array}{l}\text { Emotional } \\
\text { Recognition/ } \\
\text { Understanding }\end{array}$ & Village (3) & 78 & 4.02 & .56 & & & & \\
\hline $\begin{array}{l}\text { Emotional } \\
\text { Intelligence }\end{array}$ & $\begin{array}{l}\text { Province } \\
\text { (1) }\end{array}$ & 108 & 3.87 & .64 & $2-$ & & & \\
\hline Subscale 2: & District (2) & 88 & 3.64 & .72 & 271 & 3.558 & $.030 *$ & $1-2$ \\
\hline $\begin{array}{l}\text { Emotional } \\
\text { Facilitation }\end{array}$ & Village (3) & 78 & 3.67 & .69 & & & & \\
\hline $\begin{array}{l}\text { Emotional } \\
\text { Intelligence }\end{array}$ & $\begin{array}{l}\text { Province } \\
\text { (1) }\end{array}$ & 108 & 3.82 & .71 & $2-$ & & & \\
\hline Subscale 3: & District (2) & 88 & 3.68 & .83 & 271 & 1.057 & .349 & \\
\hline $\begin{array}{l}\text { Emotional } \\
\text { Regulation }\end{array}$ & Village (3) & 78 & 3.70 & .70 & & & & \\
\hline
\end{tabular}

As seen in Table 6, the scores of pre-service Social Studies teachers on the ISS $(F(2-271)=3.667, \mathrm{p}<.05)$ and the emotional facilitation subscale $(\mathrm{F}(2-271)=3.558$, $\mathrm{p}<.05)$ differed significantly according to the residence of longest duration. The results of Tukey's test conducted to find significantly different means showed that the difference is between province and village for intercultural sensitivity and between province and district for emotional facilitation. Given the arithmetic mean of the scores in both cases of significant difference, the difference was in favor of those who lived longest in a province (Intercultural Sensitivity $\overline{\bar{X}}=4.13$, Emotional Intelligence-Emotional Facilitation $\overline{\bar{X}}=3.87$ ). However, the scores of pre-service Social Studies teachers' on the EIS and its sub-scales of emotional recognition/understanding and emotional regulation did not differ according to the residence of longest duration.

Table 7 displays the results of the T-test for the pre-service Social Studies teachers' levels of intercultural sensitivity and emotional intelligence in relation to having friends from different countries or cultures. 
Table 7

T-Test Results for Pre-service Social Studies Teachers' Levels of Intercultural Sensitivity and Emotional Intelligence according to Having Friends from Different Countries or Cultures

\begin{tabular}{lccccccc}
\hline & $\begin{array}{c}\text { Having } \\
\text { Friends }\end{array}$ & $\mathrm{N}$ & $\mathrm{X}$ & $\mathrm{SD}$ & $\mathrm{df}$ & $\mathrm{t}$ & $\mathrm{p}$ \\
\hline Intercultural Sensitivity & Yes & 183 & 4.12 & .41 & 272 & 4.129 & $.000^{*}$ \\
& No & 91 & 3.89 & .47 & & & \\
\hline Emotional Intelligence & Yes & 183 & 3.94 & .53 & 272 & 3.665 & $.000^{*}$ \\
& No & 91 & 3.68 & .58 & & & \\
\hline Emotional Intelligence & Yes & 183 & 4.16 & .55 & 272 & 1.448 & .149 \\
Subscale 1: Emotional & No & 91 & 4.06 & .63 & & & \\
Recognition/ & & & & & & & \\
Understanding & & & & & & & \\
\hline Emotional Intelligence & Yes & 183 & 3.84 & .66 & 272 & 3.688 & $.000^{*}$ \\
Subscale 2: Emotional & No & 91 & 3.52 & .70 & & & \\
Facilitation & & & & & & & \\
\hline Emotional Intelligence & Yes & 183 & 3.85 & .71 & 272 & 3.436 & $.001^{*}$ \\
Subscale 3: Emotional & No & 91 & 3.53 & .79 & & & \\
Regulation & & & & & & & \\
$*$ p $<.05$ & & & & & & &
\end{tabular}

As seen in Table 7, the pre-service Social Studies teachers' levels of intercultural sensitivity differed statistically significantly according to having friends from different countries or cultures $(\mathrm{t}(272)=4.129, \mathrm{p}<.05)$. Given the arithmetic mean of the scores, pre-service Social Studies teachers with friends from different countries or cultures $(\bar{X}=4.12$ ) had levels of higher intercultural sensitivity than those without friends from different countries or cultures $(\bar{X}=3.89)$.

Levels of emotional intelligence amongst pre-service Social Studies teachers also differed significantly according to having friends from different countries or cultures $(\mathrm{t}(272)=3.665, \mathrm{p}<.05)$. Those with friends from different countries or cultures $(\bar{X}=3.94)$ had higher emotional intelligence than those without friends $(\bar{X}$ = 3.688). Having friends from different countries of cultures also led to significant differences in participants' scores on the sub-scales of emotional facilitation $(\mathrm{t}(272)$ $=3.68, \mathrm{p}<.05)$ and emotional regulation $(\mathrm{t}(272)=3.436, \mathrm{p}<.05)$ but not on the emotional recognition/understanding subscale $(\mathrm{t}(272)=1.448, \mathrm{p}>.05)$.

Table 8 shows the results for the T-test for pre-service Social Studies teachers' levels of intercultural sensitivity and emotional intelligence in relation to the experience of having been abroad. 
Aydemir, A.; Ulu Kalın, Ö. (2021). Relationship between levels of intercultural sensitivity and...

Table 8

T-Test Results for Pre-service Social Studies Teachers' Levels of Intercultural Sensitivity and Emotional Intelligence according to the Experience of Having Been Abroad

\begin{tabular}{lccccccc}
\hline & $\begin{array}{c}\text { Having Been } \\
\text { Abroad }\end{array}$ & $\mathrm{N}$ & $\mathrm{X}$ & $\mathrm{SD}$ & $\mathrm{df}$ & $\mathrm{t}$ & $\mathrm{p}$ \\
\hline Intercultural Sensitivity & Yes & 70 & 4.04 & .44 & 272 & -.219 & .827 \\
& No & 204 & 4.05 & .44 & & & \\
\hline Emotional Intelligence & Yes & 70 & 3.89 & .45 & 272 & .566 & .572 \\
& No & 204 & 3.85 & .59 & & & \\
\hline Emotional Intelligence & Yes & 70 & 4.08 & .57 & 272 & -.859 & .391 \\
Subscale 1: Emotional & No & 204 & 4.15 & .58 & & & \\
Recognition/ Understanding & Yes & 70 & 3.78 & .54 & 272 & .593 & .554 \\
\hline Emotional Intelligence & No & 204 & 3.72 & .73 & & & \\
Subscale 2: Emotional & Yes & 70 & 3.83 & .60 & 272 & 1.148 & .252 \\
Facilitation & No & 204 & 3.71 & .80 & & & \\
\hline Emotional Intelligence Subscale & 3: Emotional Regulation & & & & & &
\end{tabular}

Looking at the data in Table 8, it is apparent that participants' scores on the ISS $(\mathrm{t}(272)=-.219, \mathrm{p}>.05)$, the EIS $(\mathrm{t}(272)=.566, \mathrm{p}>.05)$, and its sub-scales (emotional recognition/understanding $[\mathrm{t}(272)=-.859, \mathrm{p}>.05]$, emotional facilitation $[\mathrm{t}(272)$ $=.593, \mathrm{p}>.05]$, and emotional regulation $[\mathrm{t}(272)=1.148, \mathrm{p}>.05])$ did not differ significantly according to the experience of having been abroad. Lastly, Table 9 demonstrates an analysis of results for the relationship between levels of intercultural sensitivity and emotional intelligence amongst pre-service Social Studies teachers.

Table 9

Relationship between Levels of Intercultural Sensitivity and Emotional Intelligence amongst Pre-service Social Studies Teachers'

\begin{tabular}{|c|c|c|c|c|c|c|}
\hline & & 1 & 2 & 3 & 4 & 5 \\
\hline \multirow[t]{3}{*}{ 1. Intercultural Sensitivity } & $\mathrm{r}$ & 1 & $.514^{* *}$ & $.482^{* *}$ & $.403^{* *}$ & $.402^{* *}$ \\
\hline & $\mathrm{p}$ & & .000 & .000 & .000 & .000 \\
\hline & $\mathrm{N}$ & 274 & 274 & 274 & 274 & 274 \\
\hline \multirow[t]{3}{*}{ 2. Emotional Intelligence } & $\mathrm{r}$ & & 1 & $.637^{* *}$ & $.871^{* *}$ & $.898^{* *}$ \\
\hline & $\mathrm{p}$ & & & .000 & .000 & .000 \\
\hline & $\mathrm{N}$ & 274 & 274 & 274 & 274 & 274 \\
\hline \multirow{3}{*}{$\begin{array}{l}\text { 3. Emotional Intelligence Subscale } \\
\text { 1: Emotional Recognition/ } \\
\text { Understanding }\end{array}$} & $\mathrm{r}$ & & & 1 & $.406^{* *}$ & $.331^{* *}$ \\
\hline & $\mathrm{p}$ & & & & .000 & .000 \\
\hline & $\mathrm{N}$ & 274 & 274 & 274 & 274 & 274 \\
\hline \multirow{3}{*}{$\begin{array}{l}\text { 4. Emotional Intelligence Subscale } \\
\text { 2: Emotional Facilitation }\end{array}$} & $\mathrm{r}$ & & & & 1 & $.702^{* *}$ \\
\hline & $\mathrm{p}$ & & & & & .000 \\
\hline & $\mathrm{N}$ & 274 & 274 & 274 & 274 & 274 \\
\hline \multirow{3}{*}{$\begin{array}{l}\text { 5. Emotional Intelligence Subscale } \\
\text { 3: Emotional Regulation }\end{array}$} & $\mathrm{r}$ & & & & & 1 \\
\hline & $\mathrm{p}$ & & & & & \\
\hline & $\mathrm{N}$ & 274 & 274 & 274 & 274 & 274 \\
\hline
\end{tabular}


** Correlation is significant at .01 .

It is apparent from Table 9 that there is a significant positive relationship between the levels of intercultural sensitivity and emotional intelligence $(p<.01)$ amongst pre-service Social Studies teachers. There is a significant moderate positive relationship between participants' intercultural sensitivity and their overall emotional intelligence $(\mathrm{r}=.514, \mathrm{p}<.01)$. There are also significant moderate positive relationships between participants' intercultural sensitivity and their emotional recognition/understanding $(\mathrm{r}=.482, \mathrm{p}<.01)$, emotional facilitation $(\mathrm{r}$ $=.403, \mathrm{p}<.01)$ and emotional regulation $(\mathrm{r}=.402, \mathrm{p}<.01)$.

\section{Result and Discussion}

The pre-service Social Studies teachers' scores on the ISS and the EIS were analyzed and some results were reached. Pre-service teachers' levels of emotional intelligence were investigated both in general terms and in three sub-scales (emotional recognition/understanding, emotional facilitation, and emotional regulation).

Vilà-Baños (2006) suggested that gender is critical for intercultural sensitivity and women have a higher level of intercultural sensitivity than men. Similarly, the present study found that pre-service Social Studies teachers' levels of intercultural sensitivity differed significantly by gender. Given the arithmetic mean of the scores, women had a higher level of intercultural sensitivity than men. In contrast, in their study with both Turkish and foreign students, Abaslı and Polat (2019) reported that intercultural sensitivity did not differ by gender. Üstün (2011) also concluded that gender did not lead to a significant difference in intercultural sensitivity; however, the mean score of female participants was higher than that of men. This result may be explained by women's capability of more detailed and versatile thinking.

No significant difference was found in levels of intercultural sensitivity amongst pre-service Social Studies teachers according to the type of high school attended. However, Üstün (2011) found that the type of high school attended significantly influenced the level of intercultural sensitivity. This inconsistency in the results may be due to the implementation of the studies in different years.

Ögüt (2017) concluded that participants' levels of intercultural sensitivity differed significantly according to the experience of having been abroad and having friends from different cultures. In the present study, having friends from different countries or cultures led to a different significant difference in participants' levels of intercultural sensitivity, while the experience of having been abroad did not lead to any difference.

Onur-Sezer and Bahçeli-Kahraman (2017) reported that levels of intercultural sensitivity amongst pre-service teachers' did not differ according to living in settlements such as a province, district, and village. On the contrary, Üstün (2011) found that pre-service teachers growing up in a province had a higher level of intercultural sensitivity compared to those growing up in a district or village. Consistent with the finding of Üstün (2011), the present study also found that participants who lived longest in a province had a higher level of intercultural 
sensitivity. A possible explanation for this result might be that individuals living in a province are more likely to encounter different cultures compared to those living in smaller settlements such as districts and villages. As individuals living in a province experience more different cultures, they may develop more sensitivity to these cultures.

The analysis results showed that levels of intercultural sensitivity amongst preservice Social Studies teachers' did not differ significantly according to the year of study and the experience of having been abroad.

Studies conducted on different sample groups have shown that participants' levels of emotional intelligence did not differ significantly by gender (Cook, 2006; Girgin, 2009; Yllmaz \& Zembat, 2019). Similarly, in this study, levels of emotional intelligence did not differ by gender amongst the pre-service Social Studies teacher participants.

Additionally, there were significant differences in participants' scores on the EIS and its sub-scales of emotional regulation and emotional facilitation in relation to having friends from different countries or cultures. Accordingly, those who have friends from different cultures or countries had a higher level of emotional intelligence. For the emotional facilitation and emotional regulation subscales, the difference was also in favor of those who have friends from different countries or cultures.

According to the results of analysis, the levels of emotional intelligence amongst pre-service Social Studies teachers' did not differ significantly according to the year of study. However, Yılmaz and Zembat (2019) reported that 4th-year students' levels of emotional intelligence were significantly higher compared to 1st-year students. Kayıhan (2017) also found a significant difference only in the emotional facilitation subscale of the EIS according to the year of study.

Aykutlu et al. (2019) found no significant difference in the levels of emotional intelligence amongst pre-service teachers' according to the type of high school attended and the place of residence. Likewise, in this study, pre-service Social Studies teachers' overall levels of emotional intelligence did not differ significantly according to the type of high school attended and the residence of longest duration. Pre-service teachers' scores only on the emotional facilitation sub-scale of the EIS differed significantly according to the residence of longest duration. According to the results of the analysis, the scores of pre-service Social Studies teachers on the EIS and its sub-scales did not differ significantly according to the experience of having been abroad.

Several studies have found significant correlations between emotional intelligence and various variables such as ethical reasoning, academic achievement, problem-solving skills, classroom management models, adjustment to college life, life satisfaction, professional concern, listening skills, self-regulated learning, and leadership status (Arlı et al., 2011; Aykutlu et al., 2019; Doğan-Kılıç \& Önen, 2009; Ergin et al., 2013; Kayıhan, 2017; Kıroğlu et al., 2019; Muștu, 2019; Yılmaz \& Zembat, 2019). Previous studies have also found relationships are evident between intercultural sensitivity and life satisfaction, happiness levels, attitudes towards 
multicultural education, empathy, conflict styles, and cultural intelligence (Abasl, 2018; Abaslı \& Polat, 2019; Onur-Sezer \& Bahçeli-Kahraman, 2017; Öğüt, 2017; Öksüz \& Baba-Öztürk, 2016). The current study found a significant moderate positive relationship between participants' intercultural sensitivity and their overall emotional intelligence. There were also significant moderate positive relationships between participants' intercultural sensitivity and their scores on the emotional intelligence sub-scales, i.e. emotional recognition/understanding, emotional facilitation, and emotional regulation.

\section{Suggestions}

In line with the results of the study, a number of suggestions may be offered. This study was conducted with pre-service Social Studies teachers. Further research may survey pre-service teachers from different disciplines. More generalizable conclusions can be drawn through the comparison of research findings. Especially in relation to effective citizen education, it is critically important in Social Studies classes to prepare students to become citizens who have intercultural sensitivity and can use their emotional intelligence. Thus, further research may be undertaken to develop data collection instruments that measure intercultural sensitivity and emotional intelligence levels of Social Studies teachers and middle school students or to adapt existing instruments to different sample groups. In this way, effective measures can be taken to identify the current situation and develop some values and skills more effectively. Practical classroom activities and can be organized for middle school students, case study and learning-by-doing activities can be designed for pre-service teachers, and in-service training can be offered to teachers.

\section{References}

Abaslı, K. (2018). Examınation of turkish and international students views on the relationship between intercultural sensitivity and empathy. Journal of TUBAV Science, 11(2), 20-23.

Abasl, K. \& Polat, Ş. (2019). The examination of students' views on intercultural sensitivity and cultural intelligence. Journal of Social Sciences of Mus Alparslan University, 7(1), 193-202.

Acar, F. (2002). Emotional intelligence and leadership. Erciyes University Journal of Social Sciences Institute, 1(12), 53-68.

Arlı, D., Altunay, E. \& Yalçınkaya, M. (2011). The relationship of emotional intelligence, problem solving and academic success of pre-service teachers. Academic Overview International Refereed E-Journal of Social Sciences, 25, 1-23.

Aydın, M. (2014). Society, culture and education. Ankara: Gazi.

Aykutlu, I., Bezen, S., Bayrak, C. \& Seçken, N. (2019). An examination of pre-service teachers' emotional intelligence and profession-related anxiety levels according to various variables. Gazi University Journal of Gazi Education Faculty (GUJGEF), 39(3), 16711705.

Bennett, M. J. (1998). Intercultural communication: a current perspective. In M. J. Bennett (Ed.) Basic concepts of intercultural communication: selected readings (p.1-34). Boston: Intercultural Press. 
Aydemir, A.; Ulu Kalın, Ö. (2021). Relationship between levels of intercultural sensitivity and...

Bhawuk, D. \& Brislin, D. (1992). The measurement of intercultural sensitivity using the concepts of individualism and collectivism. International Journal of Intercultural Relations, 16, 413-436.

Büyüköztürk, Ş. (2011). Data analysis handbook for social sciences (15th Edition). Ankara: Pegem.

Chen, G. M. (1997). A review of the concept of intercultural sensitivity. Paper presented at the biennial convention of the Pacific and Asia Communication Association, Honolulu, HI.

Chen, G. M. \& Starosta, W. J. (1996). Intercultural communication competence: a synthesis. Communication Yearbook, 19, 353-383.

Chen, G. M., \& Starosta, W. J. (2000). The development and validation of the intercultural sensitivity scale. Human Communication, 3, 1-15.

Cirık, İ. (2008). Multicultural education and its reflections. Hacettepe Üniversity Journal of Education, 34, 27-40.

CoHE (Council of Higher Education]). (2018). Social studies teacher training undergraduate program. Retrieved from http://www.yok.gov.tr/documents/10279/41805112 /Sosyal_Bilgileri_Ogretmenligi_Lisans_Programi.pdf

Cook, C. R. (2006). Effects of emotional intelligence on principals' leadership performance. Doctoral Dissertation, Montana State University-Bozeman College of Education Health \& Human Development, USA.

Çakar, U. \& Arbak, Y. (2004). Modern yaklaşımlar ışığında değișen duygu-zekâ ilișkisi ve duygusal zekâ. Dokuz Eylul University The Journal of Graduate School of Social Sciences, 6(3), 23-48.

Delice, M. \& Günbeyi, M. (2013). An analysis of the relationships between emotional intelligence and leadership: a survey on Turkish national police. Journal of Economics and Administrative Sciences, 27(1), 209-239.

Doğan Kılıç, E. \& Önen, Ö. (2009). Teacher candidates' emotional intelligence levels and ethical reasoning abilities. Journal of Human Sciences, 6(1), 123-163.

Dutoğlu, G. \& Tuncel, M. (2008). The relationship between candidate teachers' critical thinking tendencies and their emotional intelligence levels. Bolu Abant Izzet Baysal University Journal of Faculty of Education, 8(1), 11-32.

Erdoğdu, M. Y. (2008). Research on emotional quotient in terms of certain variables. Electronic Journal of Social Sciences, 7(23), 62-76.

Ergin, B., Kaynak, K. B., Pınarcık, Ö. \& Arslan, E. (2013). Evaluation of relationship between emotional intelligence and life satisfaction of pre-school teacher candidates. Journal of Research in Education and Teaching, 2(2), 35-42.

Fuller, T. L. (2007). Study abroad experiences and intercultural sensitivity among graduate theological students: a preliminary and exploratory investigation. Christian Higher Education, 6(4), 321-332.

Girgin, G. (2009). Evaluation of effects of some variables on emotional intelligence in student teachers. MANAS Journal of Social Studies, 22, 131-140.

Goleman, D. (1998).The emotionally intelligent leader. İstanbul: Varlık.

Güllüce, A. Ç. \& İşcan, Ö. F. (2010). The relationship between occupational burnout and emotional intelligence. Eskissehir Osmangazi University Journal of Economics and Administrative Sciences, 5(2), 7-29. 
Karaca, Ș. \& Gümüș, N. (2018). Culture and consumption. Ankara: Gazi.

Kayıhan, Ș. N. (2017). An investigation of the relationship between self-directed learning (SDL) and emotional intelligence (EI) (Unpublished Master's Thesis). Sakarya University Institute of Education, Sakarya.

Kayıhan, S.. N. \& Arslan, S. (2016). Emotional intelligence scale: A study of scale adaptation. FSM Scholarly Studies Journal of Humanities and Social Sciences, 7, 137-145.

Kıroğlu, K., Aslan, H. \& Elma, C. (2019). The relationship between teacher candidates' levels of emotional intelligence and listening skills. EKEV Academic Review, 23(78), 391-406.

Koçoğlu, E. (2014). The teachers' perceptions of the gains of social studies lessons upon cultural life. Mediterranean Journal of Humanities, IV/2, 191-205.

Lee, H. \& Kwak, Y. (2012). Development and initial validation of a trait emotional intelligence scale for Korean adults. Asia Pacific Education Review, 13(2), 209-217.

Mercan, N. (2016). Cultural sensitivity and communication skills on the relationship between an investigations. Press Academia Procedia, Global Business Research Congress (GBRC), May 26-27 2016, İstanbul.

MoNE (Ministry of National Education). (2005). Social studies curriculum (secondary schools 6 and 7 grades). Ankara: Devlet Kitapları.

MoNE (Ministry of National Education). (2018). Sosyal bilgiler dersi ögrretim programı (primary and secondary schools 4, 5, 6 and 7 grades). Ankara. Retrieved from http://mufredat.meb.gov.tr/Dosyalar/201812103847686SOSYAL\%20B\%C4\%B0LG \%C4\%B0LER\%20\%C3\%96\%C4\%9ERET\%C4\%B0M\%20PROGRAMI\%20.pdf

Muştu, D. (2019). The effect of emotional intelligence on leadership orientation of teacher candidates (Education Faculty/Anadolu University example) (Unpublished Master's Thesis). Anadolu University Institute of Education, Eskişehir.

Onur Sezer, G. \& Bahçeli Kahraman, P. (2017). The relationship between the attitudes of classroom and preschool teacher candidates towards multicultural education and their intercultural sensitivities: sample of Uludag University. Mersin University Journal of the Faculty of Education, 13(2), 550-560.

Öğ̈̈t, N. (2017). Investigation of the relationship between intercultural sensitivity level and ethnocentrism, life satisfaction and happiness levels (Unpublished Doctoral Thesis). Selçuk University Institute of Social Sciences, Konya.

Öksüz, Y. \& Baba Öztürk, M. (2016). The relationship between pre-service teachers' conflict activity styles and intercultural sensitivity. Manas Journal of Social Studies, 5(4), 1-12.

Özdemir, Y. A., Şahin Tekin, S. T. \& Esin, A. A. (2019). Introduction to sampling methods with solved examples (Revised 2nd Edition). Ankara: Seçkin.

Öztürk, A. (2006). Comparative analysis of emotional intelligence job satisfaction and burnout levels of preschool teachers according to some variables (Unpublished Master's Thesis). Selçuk University Institute of Social Sciences, Konya.

Rengi, Ö. (2014). Primary teachers' perception of cultural diversity and intercultural sensitivity (Unpublished Master's Thesis). Kocaeli University Institute of Social Sciences, Kocaeli.

Robbins, S. P. (2000). Managing today. New Jersey: Prentice Hall.

Sönmez, V. \& Alacapınar, F. G. (2019). Exemplified scientific research methods (7th Edition). Ankara: Anı. 
Aydemir, A.; Ulu Kalın, Ö. (2021). Relationship between levels of intercultural sensitivity and...

Sudak, M. K. \& Zehir, C. (2013). Types of personality, emotional intelligence, with a study on the relationship between job satisfactions. Journal of Administrative Sciences, 11(22), 414-165.

Tamam, E. \& Krauss, S. E. (2017). Ethnic-related diversity engagement differences in intercultural sensitivity among Malaysian undergraduate students. International Journal of Adolescence and Youth, 22(2), 137-150.

Tekbıyık, A. (2019). Relational Research Model. In H. Özmen \& O. Karamustafaoğlu (Eds). Research methods in education (2nd edition) (pp.163-178). Ankara: Pegem.

Tuğrul, C. (1999). Emotional intelligence. Turkish Journal of Clinical Psychiatry, 1, 12-20.

Üstün, E. (2011). Factors affecting teacher candidates' intercultural sensitivity and ethnocentrism levels (Unpublished Master's Thesis). Yıldız Teknik University Institute of Social Sciences, İstanbul.

Vilà-Baños, R. (2006). Intercultural sensitivity of teenagers: a study of educational necessities in Catalonia. Intercultural Communication Studies, XV (2), 16-22.

Westrick, J. M. \& Yuen, C. Y. M. (2007). The intercultural sensitivity of secondary teachers in Hong Kong: a comparative study with implications for professional development. Intercultural Education, 18(2), 129-145.

Yeşilyaprak, B. (2001). Implications in terms of emotional intelligence and education. Educational Administration: Theory and Practice, 25, 139-146.

Yılmaz, F. \& Göçen, S. (2013). Investigation of the prospective primary teachers' intercultural sensitivity levels in terms of certain variables. Adlyaman University Journal of Social Sciences, 6(15), 373-392.

Yılmaz, H. \& Zembat, R. (2019). THE relationship between preservice preschool teachers' emotional intelligence levels and adjustment to university life. Mehmet Akif Ersoy University Journal of Faculty of Education, 52, 118-136.

Yılmaz Karabulutlu, E., Yılmaz, S. \& Yurttaş, A. (2011). The relationship between emotional intelligence levels of students and problem- solving skills. Journal of Psychiatric Nursing, 2(2), 75-79.

Yuen, C. Y. M. \& Grossman, D.L. (2009). The intercultural sensitivity of student teachers in three cities. Compare: A Journal of Comparative and International Education, 39(3), 349-365.

\section{Biographical Statements}

Arcan AYDEMIIR graduated from Gazi University, Gazi Education Faculty, Social Studies Teaching program in 2012. In 2014, he completed his master's degree in Gazi University, Institute of Educational Sciences, Social Studies Education. In 2019, he completed his doctorate in Gazi University, Institute of Educational Sciences, Social Studies Education and received the title of doctor. He has been working as a research assistant at Artvin Coruh University, Faculty of Education, Department of Social Studies Education since 2014.

Özlem ULU KALIN completed her undergraduate education at Ankara University Faculty of Educational Sciences Department of Social Sciences Teaching (1999-2003). After that, she got her master's degree from Atatürk University Institute of Social Sciences Department of Social Sciences Teaching (2003-2007) and she also carried out her PhD education in Ataturk University Institute of Social Sciences Department of Social Sciences Teaching (2007-2011). The author, who started working as a research assistant in February 2006, at KTU 
(Karadeniz Technical University) Artvin University Faculty of Education, has been working as a faculty member at Artvin Coruh University Faculty of Education since 2011. In July 2019, she assumed the title of Associate Professor from the Inter-University Board. . 